\title{
MACROPRUDENTIAL POLICY IN ASIAN ECONOMIES
}

Soyoung Kim

\section{NO. 577}

April 2019
ADB ECONOMICS WORKING PAPER SERIES 
ADB Economics Working Paper Series

\section{Macroprudential Policy in Asian Economies}

Soyoung Kim

No. 577 | April 2019
Soyoung Kim (soyoungkim@snu.ac.kr) is professor in the Department of Economics, Seoul National University.

This paper was written as background material for the Asian Development Outlook 2018 Update theme chapter on Maintaining Stability Amid Heightened Uncertainty. 
(C) 2019 Asian Development Bank 6 ADB Avenue, Mandaluyong City, 1550 Metro Manila, Philippines

Tel +632632 4444; Fax +6326362444

www.adb.org

Some rights reserved. Published in 2019.

ISSN 2313-6537 (print), 2313-6545 (electronic)

Publication Stock No. WPS190114-2

DOI: http://dx.doi.org/10.22617/WPS190114-2

The views expressed in this publication are those of the authors and do not necessarily reflect the views and policies of the Asian Development Bank (ADB) or its Board of Governors or the governments they represent.

ADB does not guarantee the accuracy of the data included in this publication and accepts no responsibility for any consequence of their use. The mention of specific companies or products of manufacturers does not imply that they are endorsed or recommended by ADB in preference to others of a similar nature that are not mentioned.

By making any designation of or reference to a particular territory or geographic area, or by using the term "country" in this document, $A D B$ does not intend to make any judgments as to the legal or other status of any territory or area.

This work is available under the Creative Commons Attribution 3.0 IGO license (CC BY 3.0 IGO)

https://creativecommons.org/licenses/by/3.o/igo/. By using the content of this publication, you agree to be bound by the terms of this license. For attribution, translations, adaptations, and permissions, please read the provisions and terms of use at https://www.adb.org/terms-use\#openaccess.

This CC license does not apply to non-ADB copyright materials in this publication. If the material is attributed to another source, please contact the copyright owner or publisher of that source for permission to reproduce it. $\mathrm{ADB}$ cannot be held liable for any claims that arise as a result of your use of the material.

Please contact pubsmarketing@adb.org if you have questions or comments with respect to content, or if you wish to obtain copyright permission for your intended use that does not fall within these terms, or for permission to use the ADB logo.

Corrigenda to ADB publications may be found at http://www.adb.org/publications/corrigenda.

Note:

In this publication, “\$” refers to United States dollars.

The ADB Economics Working Paper Series presents data, information, and/or findings from ongoing research and studies to encourage exchange of ideas and to elicit comment and feedback about development issues in Asia and the Pacific. Since papers in this series are intended for quick and easy dissemination, the content may or may not be fully edited and may later be modified for final publication. 


\section{CONTENTS}

TABLES AND FIGURES

ABSTRACT

vii

I. INTRODUCTION 1

II. MACROPRUDENTIAL POLICY, MONETARY POLICY, AND CREDIT 2

A. Macroprudential Policy Actions 2

B. Cyclical Credit, Monetary Policy, and Macroprudential Policy 5

III. EMPIRICAL METHODOLOGY 9

A. Panel Vector Autoregression Model 9

B. Empirical Model $\quad 10$

IV. EMPIRICAL RESULTS

A. Baseline Model 11

B. Extended Results 14

C. Credit and Business Cycles 19

$\begin{array}{lll}\text { V. CONCLUSIONS } & 23\end{array}$

$\begin{array}{ll}\text { REFERENCES } & 25\end{array}$ 


\section{TABLES AND FIGURES}

\section{TABLES}

$1 \quad$ Number of Macroprudential Policy Actions in 11 Asian Economies 2

2 Cross-Correlation among Measure of Macroprudential Policy Actions, Short-Term 8 Interest Rates, and Cyclical Credit

3 Forecast Error Variance Decomposition

\section{FIGURES}

1 Measure of Macroprudential Policy Actions in 11 Asian Economies, 2000-2014

$2 \quad$ Cyclical Credit, Policy Interest Rates, and Measure of Macroprudential Policy in 6 11 Asian Economies

3 Impulse Responses

$4 \quad$ Impulse Responses-Precrisis Period

$5 \quad$ Impulse Responses-Postcrisis Period

$6 \quad$ Impulse Responses-Alternative Ordering 1

$7 \quad$ Impulse Responses-Alternative Ordering 2

8 Impulse Responses-Adding Global Financial Crisis Dummies 19

$9 \quad$ Credit and Business Cycle Indicators 


\begin{abstract}
This paper analyzes the conduct and effects of macroprudential policy in 11 Asian economies. Of these, India, the People's Republic of China, and the Republic of Korea frequently used loan-to-value ratios and required reserve ratios even before the global financial crisis. India and the People's Republic of China are the most frequent users of macroprudential policy tools. Since 2000, tightening actions have been more frequent than loosening in the 11 economies. Most took tightening actions more frequently after the global financial crisis than before it. In most of these economies, macroprudential policy tends to be tightened when credit expands. The main empirical results from the analysis, which uses panel vector autoregression models, are that contractionary macroprudential policy has significant negative effects on credit and output; and that these effects are qualitatively similar to those of monetary policy. This suggests that policy authorities may experience potential policy conflicts when credit conditions are excessive and the economy is in recession.
\end{abstract}

Keywords: credit, macroprudential policy, monetary policy, output, vector autoregression

JEL codes: E58, E60, G28 


\section{INTRODUCTION}

The global financial crisis drew attention to how important financial stability is to macroeconomic stability. Since the crisis, special attention has been paid to the conduct of macroprudential policy to ensure macroeconomic stability by securing financial stability. But even before the crisis, some Asian countries frequently used macroprudential policy. The Republic of Korea, for example, has a long tradition of imposing regulations on housing markets, such as loan-to-value ratios and debt-serviceto-income limits. India, the People's Republic of China (PRC), and the Philippines have frequently used various monetary tools, including reserve requirement ratios. Many Asian countries realized the importance of financial stability during the Asian financial crisis, and imposed restrictions to achieve internal and external financial stability.

This paper analyzes the conduct and the effect of macroprudential policy in 11 Asian economies: Hong Kong, China; India; Indonesia; Japan; Malaysia; the PRC; the Philippines; the Republic of Korea; Singapore; Taipei,China; and Thailand over 2000-2014. The paper starts by documenting various summary statistics to show how macroprudential policy is conducted in the sample Asian economies, how often they have used macroprudential policy tools, the most popular types of tools, and their increased use after the global financial crisis. The paper examines whether there has been a systematic relation between macroprudential and monetary policy, and discusses comovement properties between macroprudential policy and credit conditions.

The paper then analyzes the effects of macroprudential policy and, in particular, how they compare with the effects of monetary policy. This analysis also covers the effects on credit conditions, which can be regarded as the main target of macroprudential policy, and whether macroprudential policy affects credit conditions as intended. Because monetary policy is also likely to affect this, the effect of macroprudential policy on credit conditions is compared with that of monetary policy. The effects of macroprudential policy on key macro variables, such as output and price level, in comparison with the relatively well-known effects of monetary policy are part of this analysis.

The effects of macroprudential policy are examined to see whether they change over time. Were, for example, the effects of macroprudential policy before the global financial crisis different from the effects after the crisis? The interactions between the two policies form part of this analysis. Based on the empirical results, conclusions are drawn on some policy implications for the conduct of macroprudential and monetary policy for achieving various objectives, including financial and output stability. A structural vector autoregression (VAR) model is constructed that follows Kim and Mehrotra (2017, 2018a, 2018b) to analyze the effects empirically of monetary and macroprudential policies together. A panel structure with a fixed effect is used because the sample period is quite short.

Section II documents some basic statistics on the conduct of macroprudential policy in Asia. Section III explains the empirical methodology. Section IV presents the empirical results. Section $V$ summarizes the results. 


\section{MACROPRUDENTIAL POLICY, MONETARY POLICY, AND CREDIT}

\section{A. Macroprudential Policy Actions}

The measure of macroprudential policy actions developed by Cerutti, Claessens, and Laeven (2017) is used for the review of the basic statistics on macroprudential policy actions in the 11 Asian economies. This measure identifies quarterly changes in various prudential instruments, such as sector-specific capital buffers, capital requirements, concentration limits, interbank exposure limits, the loan-to-value ratio cap, and reserve requirements on foreign and local currency denominated accounts. For each instrument for each quarter in each economy, +1 is allocated for a tightening action and -1 for a loosening action.

Table 1 shows the summary statistics: "+" indicates the number of tightening episodes and "-" shows the number of loosening episodes. The summary statistics are reported for the full sample period spanning the first quarter (Q1) of 2000 to Q4 2014, the precrisis period from Q1 2000-Q2 2008, and the postcrisis period from Q3 2008-Q4 2014.

Table 1: Number of Macroprudential Policy Actions in 11 Asian Economies

\begin{tabular}{|c|c|c|c|c|c|c|c|c|c|c|c|c|c|c|c|c|c|}
\hline \multirow[t]{2}{*}{ Economy } & \multirow[t]{2}{*}{ Period } & \multicolumn{2}{|c|}{$\begin{array}{l}\text { Sector- } \\
\text { Specific } \\
\text { Capital } \\
\text { Buffer }\end{array}$} & \multicolumn{2}{|c|}{$\begin{array}{c}\text { Capital } \\
\text { Requirements }\end{array}$} & \multicolumn{2}{|c|}{$\begin{array}{c}\text { Concentration } \\
\text { Limit }\end{array}$} & \multicolumn{2}{|c|}{$\begin{array}{c}\text { Interbank } \\
\text { Exposure } \\
\text { Limit }\end{array}$} & \multicolumn{2}{|c|}{$\begin{array}{l}\text { Loan-to- } \\
\text { Value } \\
\text { Ratios }\end{array}$} & \multicolumn{2}{|c|}{$\begin{array}{l}\text { Reserve } \\
\text { Requirements } \\
\text { on Foreign } \\
\text { Currency }\end{array}$} & \multicolumn{2}{|c|}{$\begin{array}{c}\text { Reserve } \\
\text { Requirements } \\
\text { on Local } \\
\text { Currency }\end{array}$} & \multicolumn{2}{|c|}{ Total } \\
\hline & & + & - & + & - & + & - & + & - & + & - & + & - & + & - & + & - \\
\hline \multirow{3}{*}{$\begin{array}{l}\text { Hong Kong, } \\
\text { China }\end{array}$} & Full period & 1 & 0 & 2 & 0 & 1 & 0 & 0 & 0 & 6 & -3 & 0 & 0 & 0 & 0 & 10 & -3 \\
\hline & $\begin{array}{l}\text { Q1 2000- } \\
\text { Q2 2008 }\end{array}$ & 0 & 0 & 0 & 0 & 1 & 0 & 0 & 0 & 0 & -3 & 0 & 0 & 0 & 0 & 1 & -3 \\
\hline & $\begin{array}{l}\text { Q3 2008- } \\
\text { Q4 } 2014\end{array}$ & 1 & 0 & 2 & 0 & 0 & 0 & 0 & 0 & 6 & 0 & 0 & 0 & 0 & 0 & 9 & 0 \\
\hline \multirow[t]{3}{*}{ India } & Full period & 8 & -3 & 1 & 0 & 0 & 0 & 1 & 0 & 3 & 0 & 0 & 0 & 13 & -13 & 26 & -16 \\
\hline & $\begin{array}{l}\text { Q1 2000- } \\
\text { Q2 } 2008\end{array}$ & 7 & -1 & 0 & 0 & 0 & 0 & 1 & 0 & 0 & 0 & 0 & 0 & 10 & -6 & 18 & -7 \\
\hline & $\begin{array}{l}\text { Q3 2008- } \\
\text { Q4 } 2014\end{array}$ & 1 & -2 & 1 & 0 & 0 & 0 & 0 & 0 & 3 & 0 & 0 & 0 & 3 & -7 & 8 & -9 \\
\hline \multirow[t]{3}{*}{ Indonesia } & Full period & 0 & 0 & 1 & 0 & 2 & 0 & 0 & 0 & 2 & 0 & 2 & -1 & 2 & -1 & 9 & -2 \\
\hline & $\begin{array}{l}\text { Q1 2000- } \\
\text { Q2 2008 }\end{array}$ & 0 & 0 & 0 & 0 & 2 & 0 & 0 & 0 & 0 & 0 & 0 & 0 & 0 & 0 & 2 & 0 \\
\hline & $\begin{array}{l}\text { Q3 2008- } \\
\text { Q4 } 2014\end{array}$ & 0 & 0 & 1 & 0 & 0 & 0 & 0 & 0 & 2 & 0 & 2 & -1 & 2 & -1 & 7 & -2 \\
\hline \multirow[t]{3}{*}{ Japan } & Full period & 0 & 0 & 2 & 0 & 0 & 0 & 0 & 0 & 0 & 0 & 0 & 0 & 0 & 0 & 2 & 0 \\
\hline & $\begin{array}{l}\text { Q1 2000- } \\
\text { Q2 } 2008\end{array}$ & 0 & 0 & 0 & 0 & 0 & 0 & 0 & 0 & 0 & 0 & 0 & 0 & 0 & 0 & 0 & 0 \\
\hline & $\begin{array}{l}\text { Q3 2008- } \\
\text { Q4 } 2014\end{array}$ & 0 & 0 & 2 & 0 & 0 & 0 & 0 & 0 & 0 & 0 & 0 & 0 & 0 & 0 & 2 & 0 \\
\hline \multirow[t]{3}{*}{ Malaysia } & Full period & 3 & 0 & 1 & 0 & 0 & 0 & 0 & 0 & 2 & 0 & 0 & 0 & 3 & -3 & 9 & -3 \\
\hline & $\begin{array}{l}\text { Q1 2000- } \\
\text { Q2 } 2008\end{array}$ & 1 & 0 & 0 & 0 & 0 & 0 & 0 & 0 & 0 & 0 & 0 & 0 & 0 & 0 & 1 & 0 \\
\hline & $\begin{array}{l}\text { Q3 2008- } \\
\text { Q4 } 2014\end{array}$ & 2 & 0 & 1 & 0 & 0 & 0 & 0 & 0 & 2 & 0 & 0 & 0 & 3 & -3 & 8 & -3 \\
\hline \multirow{3}{*}{$\begin{array}{l}\text { People's } \\
\text { Republic of } \\
\text { China }\end{array}$} & Full period & 0 & 0 & 1 & 0 & 1 & 0 & 0 & 0 & 9 & -1 & 3 & 0 & 15 & -5 & 29 & -6 \\
\hline & $\begin{array}{l}\text { Q1 2000- } \\
\text { Q2 2008 }\end{array}$ & 0 & 0 & 0 & 0 & 1 & 0 & 0 & 0 & 4 & 0 & 3 & 0 & 10 & 0 & 18 & 0 \\
\hline & $\begin{array}{l}\text { Q3 2008- } \\
\text { Q4 } 2014\end{array}$ & 0 & 0 & 1 & 0 & 0 & 0 & 0 & 0 & 5 & -1 & 0 & 0 & 5 & -5 & 11 & -6 \\
\hline
\end{tabular}


Table 1 continued

\begin{tabular}{|c|c|c|c|c|c|c|c|c|c|c|c|c|c|c|c|c|c|}
\hline \multirow[t]{2}{*}{ Economy } & \multirow[t]{2}{*}{ Period } & \multicolumn{2}{|c|}{$\begin{array}{l}\text { Sector- } \\
\text { Specific } \\
\text { Capital } \\
\text { Buffer }\end{array}$} & \multicolumn{2}{|c|}{$\begin{array}{c}\text { Capital } \\
\text { Requirements }\end{array}$} & \multicolumn{2}{|c|}{$\begin{array}{c}\text { Concentration } \\
\text { Limit }\end{array}$} & \multicolumn{2}{|c|}{$\begin{array}{l}\text { Interbank } \\
\text { Exposure } \\
\text { Limit }\end{array}$} & \multicolumn{2}{|c|}{$\begin{array}{l}\text { Loan-to- } \\
\text { Value } \\
\text { Ratios }\end{array}$} & \multicolumn{2}{|c|}{$\begin{array}{l}\text { Reserve } \\
\text { Requirements } \\
\text { on Foreign } \\
\text { Currency }\end{array}$} & \multicolumn{2}{|c|}{$\begin{array}{c}\text { Reserve } \\
\text { Requirements } \\
\text { on Local } \\
\text { Currency }\end{array}$} & \multicolumn{2}{|c|}{ Total } \\
\hline & & + & - & + & - & + & - & + & - & + & - & + & - & + & - & + & - \\
\hline \multirow[t]{3}{*}{ Philippines } & Full period & 1 & 0 & 2 & 0 & 1 & 0 & 0 & 0 & 1 & -1 & 0 & 0 & 9 & -5 & 14 & -6 \\
\hline & $\begin{array}{l}\text { Q1 2000- } \\
\text { Q2 2008 }\end{array}$ & 0 & 0 & 1 & 0 & 1 & 0 & 0 & 0 & 0 & -1 & 0 & 0 & 6 & -3 & 8 & -4 \\
\hline & $\begin{array}{l}\text { Q3 2008- } \\
\text { Q4 } 2014\end{array}$ & 1 & 0 & 1 & 0 & 0 & 0 & 0 & 0 & 1 & 0 & 0 & 0 & 3 & -2 & 6 & -2 \\
\hline \multirow{3}{*}{$\begin{array}{l}\text { Republic of } \\
\text { Korea }\end{array}$} & Full period & 1 & 0 & 2 & 0 & 0 & 0 & 0 & 0 & 8 & -4 & 0 & 0 & 1 & 0 & 12 & -4 \\
\hline & $\begin{array}{l}\text { Q1 2000- } \\
\text { Q2 2008 }\end{array}$ & 1 & 0 & 0 & 0 & 0 & 0 & 0 & 0 & 6 & -1 & 0 & 0 & 1 & 0 & 8 & -1 \\
\hline & $\begin{array}{l}\text { Q3 2008- } \\
\text { Q4 } 2014 \\
\end{array}$ & 0 & 0 & 2 & 0 & 0 & 0 & 0 & 0 & 2 & -3 & 0 & 0 & 0 & 0 & 4 & -3 \\
\hline \multirow[t]{3}{*}{ Singapore } & Full period & 0 & 0 & 2 & 0 & 3 & 0 & 0 & 0 & 5 & 0 & 0 & 0 & 1 & 0 & 11 & 0 \\
\hline & $\begin{array}{l}\text { Q1 2000- } \\
\text { Q2 2008 }\end{array}$ & 0 & 0 & 0 & 0 & 2 & 0 & 0 & 0 & 1 & 0 & 0 & 0 & 1 & 0 & 4 & 0 \\
\hline & $\begin{array}{l}\text { Q3 2008- } \\
\text { Q4 } 2014\end{array}$ & 0 & 0 & 2 & 0 & 1 & 0 & 0 & 0 & 4 & 0 & 0 & 0 & 0 & 0 & 7 & 0 \\
\hline \multirow[t]{3}{*}{ Taipei,China } & Full period & 0 & 0 & 2 & 0 & 0 & 0 & 0 & 0 & 2 & 0 & 3 & -5 & 2 & -2 & 9 & -7 \\
\hline & $\begin{array}{l}\text { Q1 2000- } \\
\text { Q2 2008 }\end{array}$ & 0 & 0 & 0 & 0 & 0 & 0 & 0 & 0 & 0 & 0 & 3 & -5 & 0 & -2 & 3 & -7 \\
\hline & $\begin{array}{l}\text { Q3 2008- } \\
\text { Q4 } 2014\end{array}$ & 0 & 0 & 2 & 0 & 0 & 0 & 0 & 0 & 2 & 0 & 0 & 0 & 2 & 0 & 6 & 0 \\
\hline \multirow[t]{3}{*}{ Thailand } & Full period & 4 & 0 & 1 & 0 & 0 & 0 & 0 & 0 & 1 & -1 & 2 & -2 & 0 & 0 & 8 & -3 \\
\hline & $\begin{array}{l}\text { Q1 2000- } \\
\text { Q2 2008 }\end{array}$ & 0 & 0 & 0 & 0 & 0 & 0 & 0 & 0 & 1 & 0 & 2 & -2 & 0 & 0 & 3 & -2 \\
\hline & $\begin{array}{l}\text { Q3 2008- } \\
\text { Q4 } 2014\end{array}$ & 4 & 0 & 1 & 0 & 0 & 0 & 0 & 0 & 0 & -1 & 0 & 0 & 0 & 0 & 5 & -1 \\
\hline \multirow[t]{3}{*}{ Total } & Full period & 18 & -3 & 17 & 0 & 8 & 0 & 1 & 0 & 39 & -10 & 10 & -8 & 46 & -29 & 139 & -50 \\
\hline & $\begin{array}{l}\text { Q1 2000- } \\
\text { Q2 2008 }\end{array}$ & 9 & -1 & 1 & 0 & 7 & 0 & 1 & 0 & 12 & -5 & 8 & -7 & 28 & -11 & 66 & -24 \\
\hline & $\begin{array}{l}\text { Q3 2008- } \\
\text { Q4 } 2014\end{array}$ & 9 & -2 & 16 & 0 & 1 & 0 & 0 & 0 & 27 & -5 & 2 & -1 & 18 & -18 & 73 & -26 \\
\hline
\end{tabular}

$+=$ tightening episodes, $-=$ loosening episodes.

Source: Author.

All economies in the sample took macroprudential policy actions more than once in the review period. India and the PRC were the most frequent. India took tightening actions 26 times and loosening actions 16 times; the PRC tightened 29 times and loosened six times. All other economies took more than 10 macroprudential policy actions-except Japan, which did this twice. In all the economies, tightening actions (139) exceeded loosening actions (50). Singapore tightened 11 times, but took no loosening action; the Republic of Korea tightened 12 times and took only two loosening actions. It is not surprising that tightening actions were more frequently taken than loosening actions because policy authorities were likely to do some tightening as they realized the importance of securing financial stability.

The periods before and after the global financial crisis are then compared. Tightening actions postcrisis were taken more frequently than loosening actions in most economies in the sample. This may reflect that many of them put more emphasis on financial stability after the crisis, though this was not the case in India, the PRC, the Philippines, and the Republic of Korea. These economies were frequent users of macroprudential policy actions even before the crisis. The most frequently used macroprudential tools were the loan-to-value ratio and reserve requirements on local currency 
denominated accounts; both are traditional macroprudential policy tools. Changes in the reserve requirements on local currency denominated accounts were used 46 times as tightening actions and 29 times as loosening actions; changes in the loan-to-value ratio were made 39 times as tightening actions and 10 as loosening ones.

Tightening actions in capital requirements and loan-to-value ratios were taken more frequently in the postcrisis period than in the precrisis period. Tightening actions in capital requirements were taken only once precrisis but 16 times postcrisis - a reflection of how tightening capital requirements was regarded as an essential tool for securing financial stability after the global financial crisis. Even so, this was a fairly new tool for many Asian countries that started to use it after the crisis. Tightening actions in the loan-to-value ratio were taken 12 times before the crisis in the 11 economies, and 27 times after it. The loan-to-value ratio was used as a macroprudential policy tool in some countries even before the crisis, but it was used in more countries after the global financial crisis.

Figure 1 shows the overall measure of macroprudential policy actions for the 11 economies. The index for each economy is constructed by allocating +1 for a tightening and -1 for a loosening action of each instrument for each economy, and then summing the values of all instruments at each quarter and accumulating the values over time for each economy. This overall measure, comprising all changes by all instruments, is used as the measure of macroprudential policy actions of each economy in this analysis. Since 2000, as the figure shows, all the economies tended to tighten macroprudential policy. By 2014, the measure is positive in all the economies, which implies that they tightened more than they loosened. In 2014, the measure is largest in the PRC, implying that tightening actions - on a net basis after taking out the number of loosening actions-was most frequently used in this country.

Figure 1: Measure of Macroprudential Policy Actions in 11 Asian Economies, 2000-2014

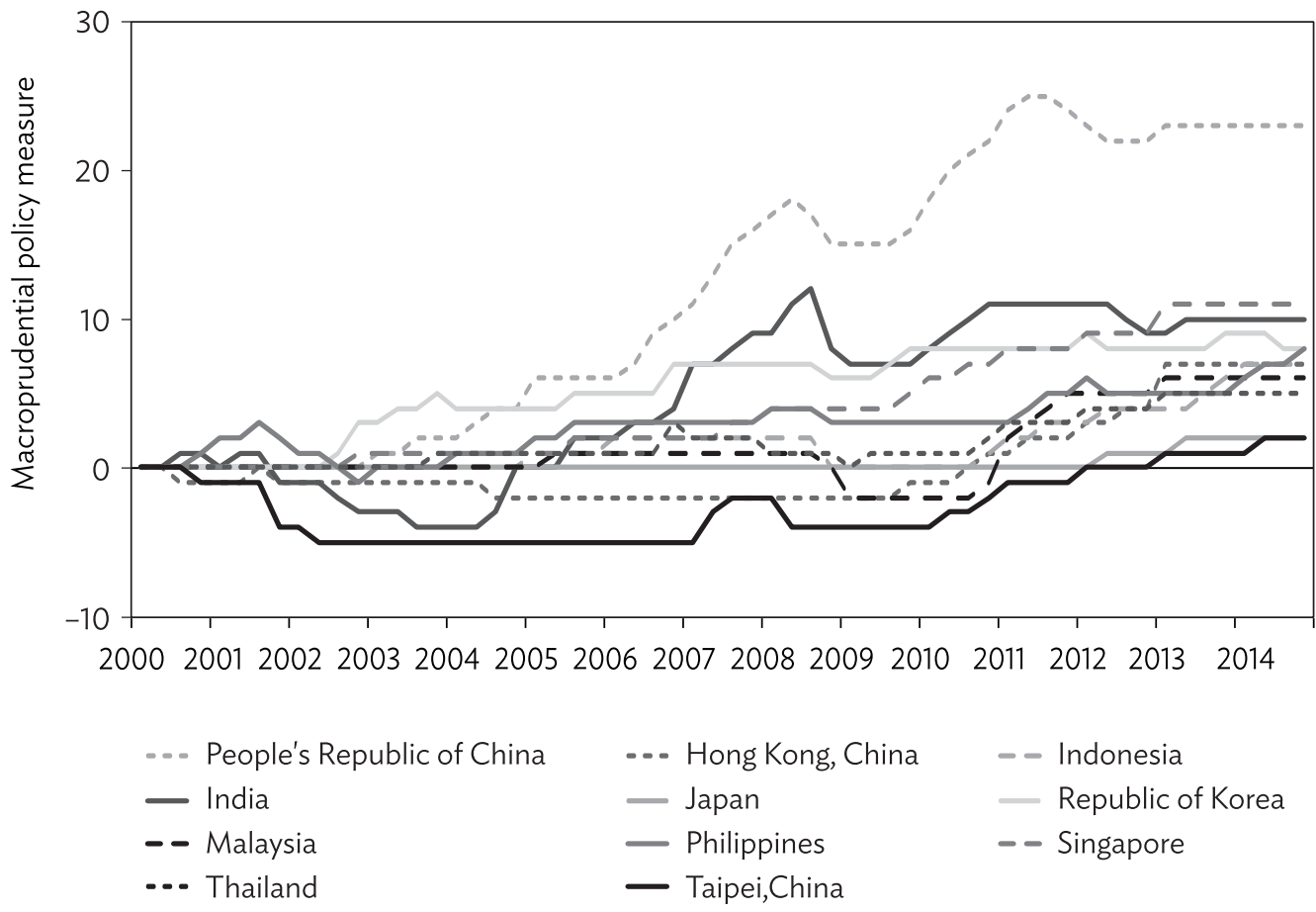

Source: Author. 


\section{B. Cyclical Credit, Monetary Policy, and Macroprudential Policy}

This section shows the relationship between cyclical credit, monetary policy, and macroprudential policy in the 11 Asian economies to infer the interactions among credit condition, monetary policy, and macroprudential policy. Figure 2 shows the measure of macroprudential policy (as explained in the previous section), the short-term interest rate as the measure of monetary policy, and the cyclical credit in each economy. Credit conditions can be seen as an indicator of financial condition, which can be regarded as the target of macroprudential policy. Kaminsky and Reinhart (1999), Schularick and Taylor (2012), and other studies suggest that monitoring credit is important because strong credit growth typically precedes crises. IMF-BIS Financial Stability Board (2011) discusses the important role that macroprudential policy plays in mitigating excessive credit expansion. The bank credit data in Figure 2 is deflated by the consumer price index and converted into the real term. ${ }^{1}$ A Hodrick-Prescott filter is then applied to extract the trend and cyclical component. ${ }^{2}$

Figure 2 shows that in almost all of the 11 economies, macroprudential policy tended to be tightened when credit expands, like what happened in Hong Kong, China from 2009 to 2011; in India from 2004 to 2007; in Indonesia from 2010 to 2013; in Japan from 2012 to 2013; in Malaysia from 2010 to 2012; in the Philippines from 2008 to 2014; in the Republic of Korea from 2005 to 2008; in Singapore from 2010 to 2014; in Thailand from 2010 to 2013; and in Taipei,China from 2009 to 2011. These observations may be interpreted as macroprudential policy reactions to reduce credit when it is excessive.

$1 \quad$ Kim and Mehrotra (2017, 2018a, 2018b), among other studies, use the ratio of total private sector credit to nonfinancial sector credit. This study, however, uses bank credit because total credit data are not available for some Asian economies, including the Philippines and Taipei,China.

2 Borio and Drehmann (2009), among other studies, suggest that the frequency of credit or a financial cycle is lower than the usual business cycle. Following Borio and Drehmann (2009) and Kim and Mehrotra (2017), the smoothing parameter lambda is set at 400,000 when the Hodrick-Prescott filter is applied. 
Figure 2: Cyclical Credit, Policy Interest Rates, and Measure of Macroprudential Policy in 11 Asian Economies
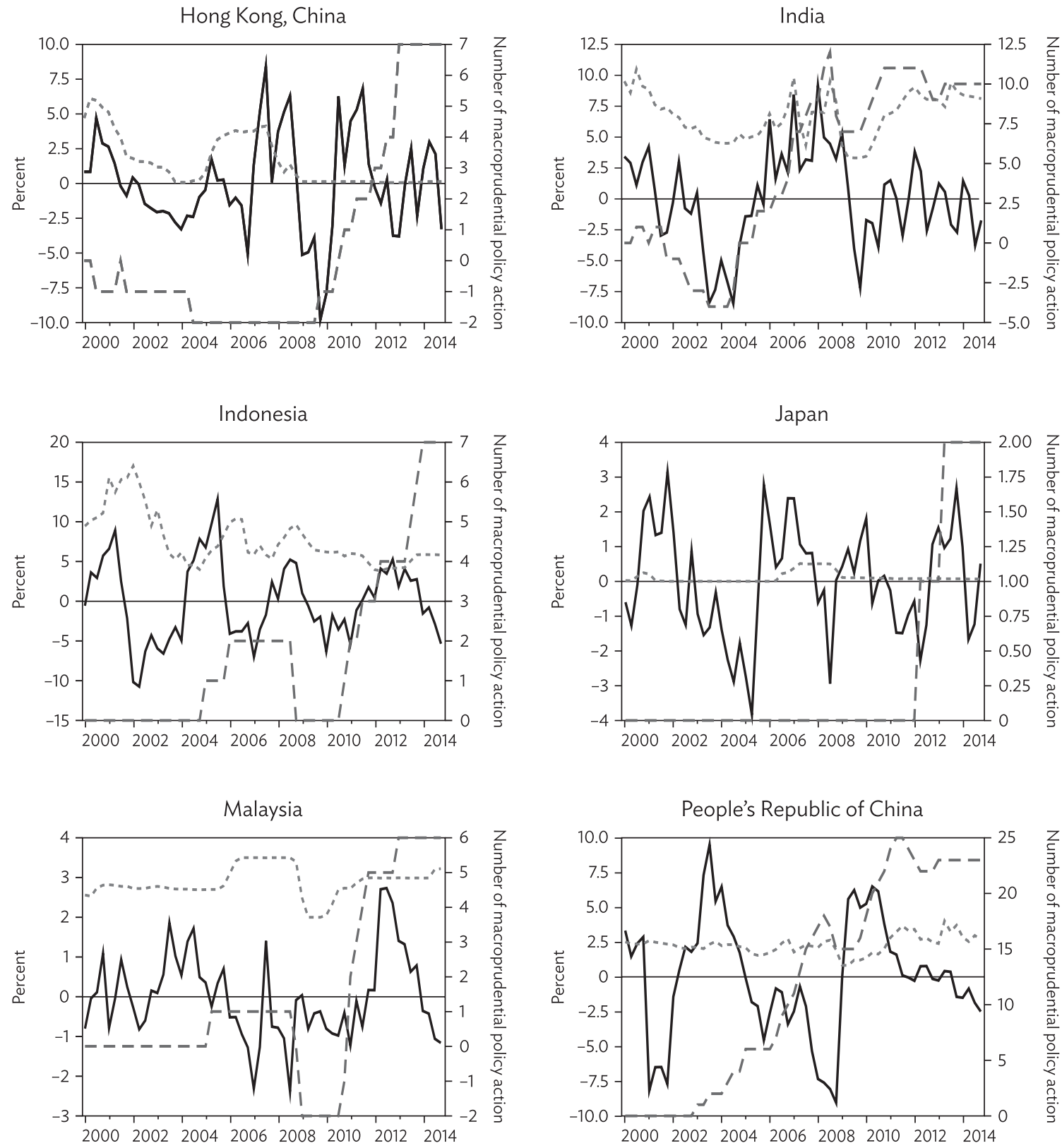

\footnotetext{
- Real credit (left)

- - - Short-term interest rate (left)

- - Measure of macroprudential policy action (right)
} 
Figure 2: Cyclical Credit, Policy Interest Rates, and Measure of Macroprudential Policy in 11 Asian Economies (continued)
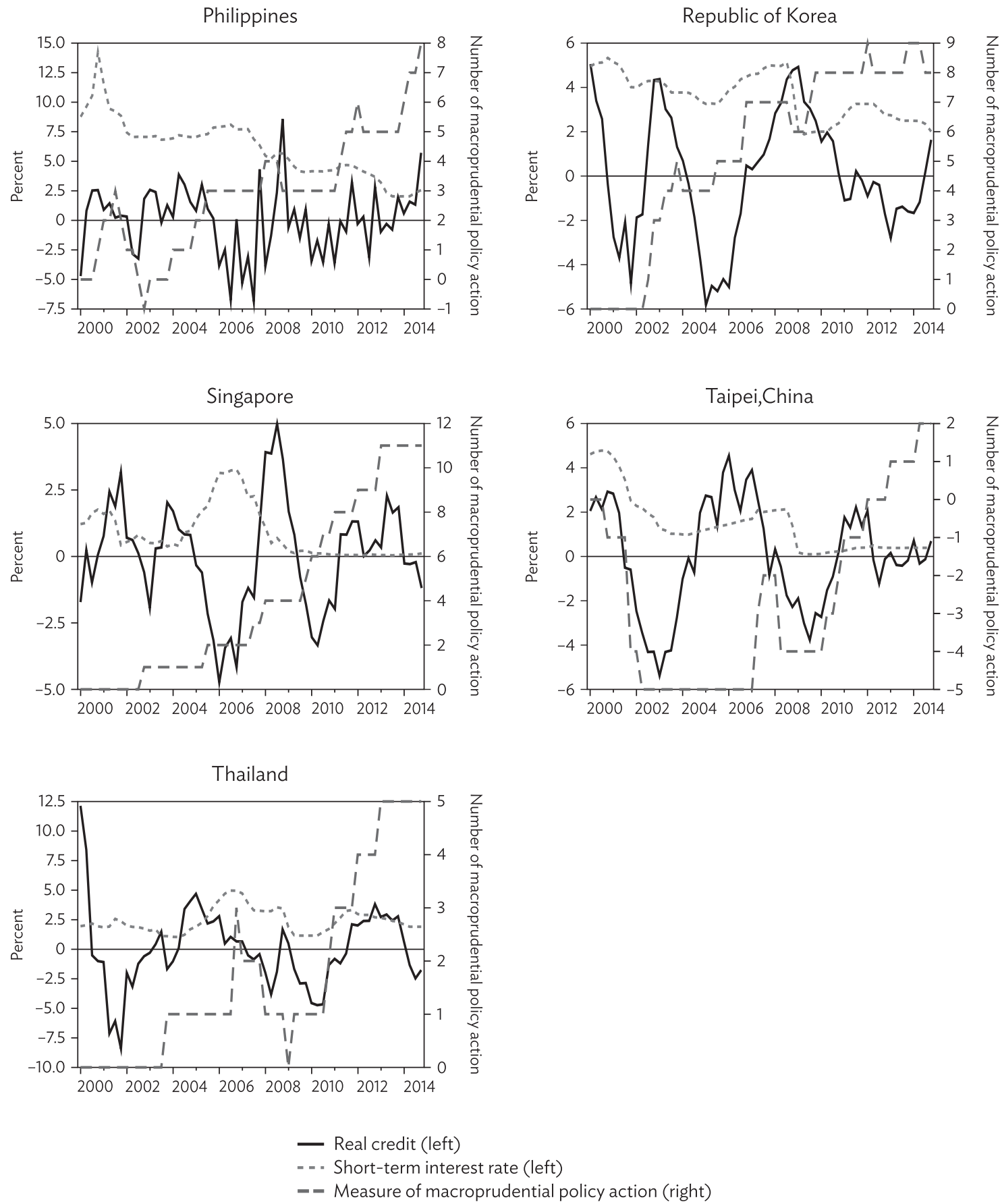
Table $2 \mathrm{~b}$ shows the cross-correlation between cyclical credit at time $t$ and the measure of macroprudential policy actions at time $t-k$ for various $k$. The correlation is mostly positive in all the sample economies, and there are no cases in which contemporaneous correlation is negative. The correlation between cyclical credit at time $t$ and the measure of macroprudential policy actions at time $t-k$ for negative $k$, which may be interpreted as how macroprudential policy reacts to credit expansion over time, is mostly positive. This suggests that macroprudential policy has been used to stabilize credit conditions. The positive correlation is especially large in Hong Kong, China; Japan; Malaysia; and Thailand. But not many cases are found in Figure 2 in which cyclical credit and short-term interest rates move together. Cross-correlations between the two tend to be negative in most economies, as Table 2c shows. The exceptions are Hong Kong, China; the Republic of Korea; and Taipei,China, where the correlations are mostly positive. The cross-correlations between cyclical credit at time $t$ and the short-term interest rates at time $t-k$ for positive $k$ is negative in all economies except for the Republic of Korea and Hong Kong, China. This may reflect the negative effect of interest rate increases on credit conditions.

Figure 2 and Table $2 a$ show the relation between the measure of macroprudential policy actions and short-term interest rates. Contemporaneous correlations are positive in Indonesia, Malaysia, the PRC, and Thailand, but negative in India; Hong Kong, China; Japan; the Philippines; the Republic of Korea; and Singapore. Positive correlation may imply that two policies are used complementarily, and negative correlation that one policy is used to mitigate the effects of the other policy.

\section{Table 2: Cross-Correlation among Measure of Macroprudential Policy Actions, Short-Term Interest Rates, and Cyclical Credit}

(a) Measure of macroprudential policy actions ( $t)$ and short-term interest rate $(t-k)$

\begin{tabular}{lrrrrrrrrr}
\hline & \multicolumn{1}{c}{$k$} & \multicolumn{1}{c}{$k$} \\
\cline { 2 - 9 } Economies & -4 & -3 & -2 & -1 & 0 & 1 & 2 & \multicolumn{1}{c}{3} & \multicolumn{1}{c}{4} \\
\hline Hong Kong, China & -0.47 & -0.47 & -0.46 & -0.45 & -0.43 & -0.38 & -0.33 & -0.28 & -0.23 \\
India & -0.55 & -0.54 & -0.51 & -0.48 & -0.45 & -0.39 & -0.35 & -0.30 & -0.25 \\
Indonesia & 0.03 & 0.12 & 0.19 & 0.26 & 0.33 & 0.36 & 0.35 & 0.37 & 0.36 \\
Japan & -0.12 & -0.11 & -0.12 & -0.12 & -0.13 & -0.12 & -0.11 & -0.10 & -0.08 \\
Malaysia & 0.08 & 0.20 & 0.29 & 0.38 & 0.45 & 0.45 & 0.4 & 0.34 & 0.27 \\
People's Republic of China & 0.11 & 0.17 & 0.22 & 0.28 & 0.34 & 0.36 & 0.36 & 0.35 & 0.34 \\
Philippines & -0.57 & -0.57 & -0.61 & -0.66 & -0.71 & -0.68 & -0.65 & -0.61 & -0.54 \\
Republic of Korea & -0.55 & -0.58 & -0.60 & -0.61 & -0.63 & -0.59 & -0.56 & -0.53 & -0.48 \\
Singapore & -0.50 & -0.52 & -0.54 & -0.56 & -0.57 & -0.55 & -0.52 & -0.49 & -0.46 \\
Taipei,China & -0.33 & -0.24 & -0.15 & -0.07 & 0.00 & 0.03 & 0.05 & 0.06 & 0.04 \\
Thailand & 0.17 & 0.21 & 0.22 & 0.20 & 0.20 & 0.20 & 0.18 & 0.16 & 0.15 \\
\hline
\end{tabular}

(b) Cyclical credit ( $t$ ) and measure of macroprudential policy actions $(t-k)$

\begin{tabular}{lccccccccc}
\hline & \multicolumn{10}{c}{$k$} \\
\cline { 2 - 11 } Economies & -4 & -3 & -2 & -1 & 0 & 1 & 2 & 3 & 4 \\
\hline Hong Kong, China & 0.28 & 0.32 & 0.38 & 0.43 & 0.45 & 0.45 & 0.45 & 0.42 & 0.40 \\
India & 0.45 & 0.42 & 0.39 & 0.34 & 0.28 & 0.23 & 0.18 & 0.12 & 0.04 \\
Indonesia & 0.22 & 0.24 & 0.23 & 0.22 & 0.20 & 0.21 & 0.21 & 0.20 & 0.20 \\
Japan & 0.27 & 0.35 & 0.39 & 0.40 & 0.43 & 0.43 & 0.41 & 0.36 & 0.32 \\
\hline & & & & & & & \multicolumn{5}{c}{ continued on next page }
\end{tabular}


Table 2 continued

\begin{tabular}{lccccccccc}
\hline & \multicolumn{1}{c}{$k$} & \multicolumn{1}{c}{$k$} \\
\cline { 2 - 10 } Economies & -4 & -3 & -2 & -1 & 0 & 1 & 2 & 3 & 4 \\
\hline Malaysia & 0.36 & 0.41 & 0.45 & 0.49 & 0.52 & 0.52 & 0.52 & .0 .50 & 0.47 \\
People's Republic of China & 0.01 & 0.01 & 0.00 & 0.00 & 0.00 & 0.00 & 0.00 & 0.00 & -0.01 \\
Philippines & -0.10 & -0.03 & -0.02 & 0.08 & 0.13 & 0.12 & 0.12 & 0.13 & 0.14 \\
Republic of Korea & 0.23 & 0.23 & 0.22 & 0.20 & 0.18 & 0.19 & 0.20 & 0.20 & 0.18 \\
Singapore & 0.01 & 0.07 & 0.13 & 0.19 & 0.25 & 0.29 & 0.33 & 0.36 & 0.38 \\
Taipei,China & 0.17 & 0.22 & 0.25 & 0.26 & 0.24 & 0.28 & 0.11 & 0.03 & -0.07 \\
Thailand & 0.15 & 0.21 & 0.26 & 0.31 & 0.36 & 0.41 & 0.44 & 0.44 & 0.43 \\
\hline
\end{tabular}

(c) Cyclical credit ( $t)$ and short-term interest rate $(t-k)$

\begin{tabular}{lccccccccc}
\hline & \multicolumn{1}{c}{$k$} & \multicolumn{1}{c}{$k$} \\
\cline { 2 - 9 } Economies & -4 & -3 & -2 & -1 & 0 & 1 & \multicolumn{1}{c}{2} & \multicolumn{1}{c}{3} & \multicolumn{1}{c}{4} \\
\hline Hong Kong, China & 0.00 & 0.08 & 0.17 & 0.25 & 0.30 & 0.25 & 0.20 & 0.15 & 0.09 \\
India & -0.11 & -0.11 & -0.13 & -0.17 & -0.17 & -0.19 & -0.25 & -0.31 & -0.34 \\
Indonesia & 0.53 & 0.47 & 0.32 & 0.14 & -0.05 & -0.19 & -0.35 & -0.46 & -0.51 \\
Japan & -0.14 & -0.10 & -0.10 & -0.11 & -0.12 & -0.10 & -0.10 & -0.08 & -0.04 \\
Malaysia & -0.05 & -0.07 & -0.10 & -0.14 & -0.16 & -0.18 & -0.20 & -0.19 & -0.19 \\
People's Republic of China & 0.45 & 0.34 & 0.23 & 0.10 & -0.07 & -0.17 & -0.17 & -0.14 & -0.14 \\
Philippines & 0.11 & 0.10 & 0.08 & 0.03 & -0.05 & -0.09 & -0.14 & -0.18 & -0.20 \\
Republic of Korea & -0.27 & -0.18 & -0.09 & 0.00 & 0.09 & 0.11 & 0.12 & 0.14 & 0.16 \\
Singapore & -0.36 & -0.40 & -0.44 & -0.48 & -0.49 & $-0,47$ & -0.45 & -0.41 & -0.37 \\
Taipei,China & 0.40 & 0.42 & 0.42 & 0.40 & 0.34 & 0.22 & 0.07 & -0.09 & -0.25 \\
Thailand & -0.05 & -0.07 & -0.09 & -0.11 & -0.13 & -0.11 & -0.11 & -0.14 & -0.17 \\
\hline
\end{tabular}

Source: Author.

\section{EMPIRICAL METHODOLOGY}

\section{A. Panel Vector Autoregression Model}

Assume that economy $i(i=1,2, \ldots, N)$ is described by the following structural form equation:

$$
G(L) y_{t}^{i}=d^{i}+C(L) x_{t}+e_{t}^{i}
$$

where $G(L)$ and $C(L)$ are matrix polynomials in the lag operator $L, y_{t}^{i}$ is an $M \times 1$ data vector of endogenous variables for country $i$ at time $t, x_{t}$ is an $K \times 1$ data vector of exogenous or world variables, $d^{i}$ is an $M \times 1$ constant matrix for country fixed effects, $M$ is the number of endogenous variables in the model, $K$ is the number of exogenous variables in the model, and $e_{t}^{i}$ is a vector of structural disturbances. By assuming that structural disturbances are mutually uncorrelated, $\operatorname{var}\left(e_{t}^{i}\right)$ can be denoted as $\Lambda$, which is a diagonal matrix where the diagonal elements are the variances of structural disturbances. The individual fixed effect, $d^{i}$, is introduced to control for country-specific timeinvariant factors that are not considered in the model. 
The following reduced form panel VAR with the individual fixed effects is estimated:

$$
y_{t}^{i}=c^{i}+B(L) y_{t-1}^{i}+D(L) x_{t}+u_{t}^{i}
$$

Where $c^{i}$ is an $M \times 1$ constant vector for country fixed effects, $B(L)$ and $D(L)$ are matrix polynomials in the lag operator $L, u^{i}$ is an $M \times 1$ vector of reduced form residuals, and $\operatorname{var}\left(u_{t}^{i}\right)=\Sigma$.

The parameters of the structural form equation can be recovered from the estimated parameters of the reduced form equation in several ways. The identification schemes under consideration impose recursive 0 restrictions on contemporaneous structural parameters by applying Cholesky decomposition to the variance-covariance matrix of reduced form residuals, $\Sigma$, as in Sims (1980).

\section{B. Empirical Model}

Kim and Mehrotra (2017, 2018a, 2018b) are followed for the empirical model. They identify monetary and macroprudential policies, and analyze their effects in a unifying empirical framework.

Five endogenous variables are included. The vector of endogenous variables, $y^{i}$, is $\left[R G D P^{i}\right.$, $\left.C R D^{i}, C P I^{i}, P P^{i}, R^{i}\right]$ ', where RGDP is real gross domestic product, $C R D$ is real credit, $C P I$ is the consumer price index, $\mathrm{PP}$ is the measure of macroprudential policy actions, and $\mathrm{R}$ is the short-term interest rate. Because it is desirable to analyze the effects of two policy shocks, two policy instruments $-R$ for monetary policy and PP for macroprudential policy-are used. The measure developed by Cerutti, Claessens, and Laeven (2017) is used as the measure of macroprudential policy actions, as shown in Figure 1. RGDP and CPI are included in the model because they are key macro variables and regarded as the main target variables of monetary policy. CRD, which can be considered as the target for macroprudential policy, is also included.

Two exogenous variables are considered. The vector of exogenous variables, $x$, is [USRGDP, FFR]', where USRGDP is the real gross domestic product of the United States (US) and FFR is the shadow federal funds rate (Wu and Xia 2016). After the global financial crisis, FFR was close to 0, but unconventional monetary policy was conducted. The shadow federal funds rate is constructed to take account of these policy actions by the US under the 0 lower bound. These variables are included because monetary policy and real activity in the US have a strong influence on the monetary, financial, and economic condition of Asian economies.

For identification, the two policy instruments $(P P, R)$ are assumed to be contemporaneously exogenous to policy target variables (RGDP, CPI, CRD). Under this assumption, policy authorities set policy instruments after observing the current and lagged values of target variables, and the lagged values of all variables. This structure can be regarded as an extension of Christiano, Eichenbaum, and Evans (1999), which identifies only monetary policy shock by assuming that the monetary policy instrument $\mathrm{R}$ is contemporaneously exogenous to RGDP and CPI.

An assumption on the ordering between PP and $\mathrm{R}$ is also needed. In the baseline model, PP is assumed to be contemporaneously exogenous to $\mathrm{R}$. This assumption does not have a clear justification, but the results are similar-and even $\mathrm{R}$ is assumed to be contemporaneously exogenous to PP. The results are also similar under alternative identifying assumptions, and some of them are given in the following section on the empirical results. 
Quarterly data are used. The sample periods are from Q1 2000 to Q4 2014 for all 11 economies, except Indonesia (from Q1 2001 to Q4 2014). The sample periods are determined by data availability. A logarithm is taken for CPI, RGDP, USRGDP, and CRD; and a constant term and two lags are assumed.

\section{EMPIRICAL RESULTS}

\section{A. Baseline Model}

Figure 3 shows the impulse responses with 90\% probability bands over 24 quarters. Each of the figure's columns shows the responses of each variable to a different shock. The types of shocks are at the top of each column and the responding variables are written at the far left of each row. For example, the fourth column shows the impulse responses to macroprudential policy shocks, and the fifth column to monetary policy shocks.

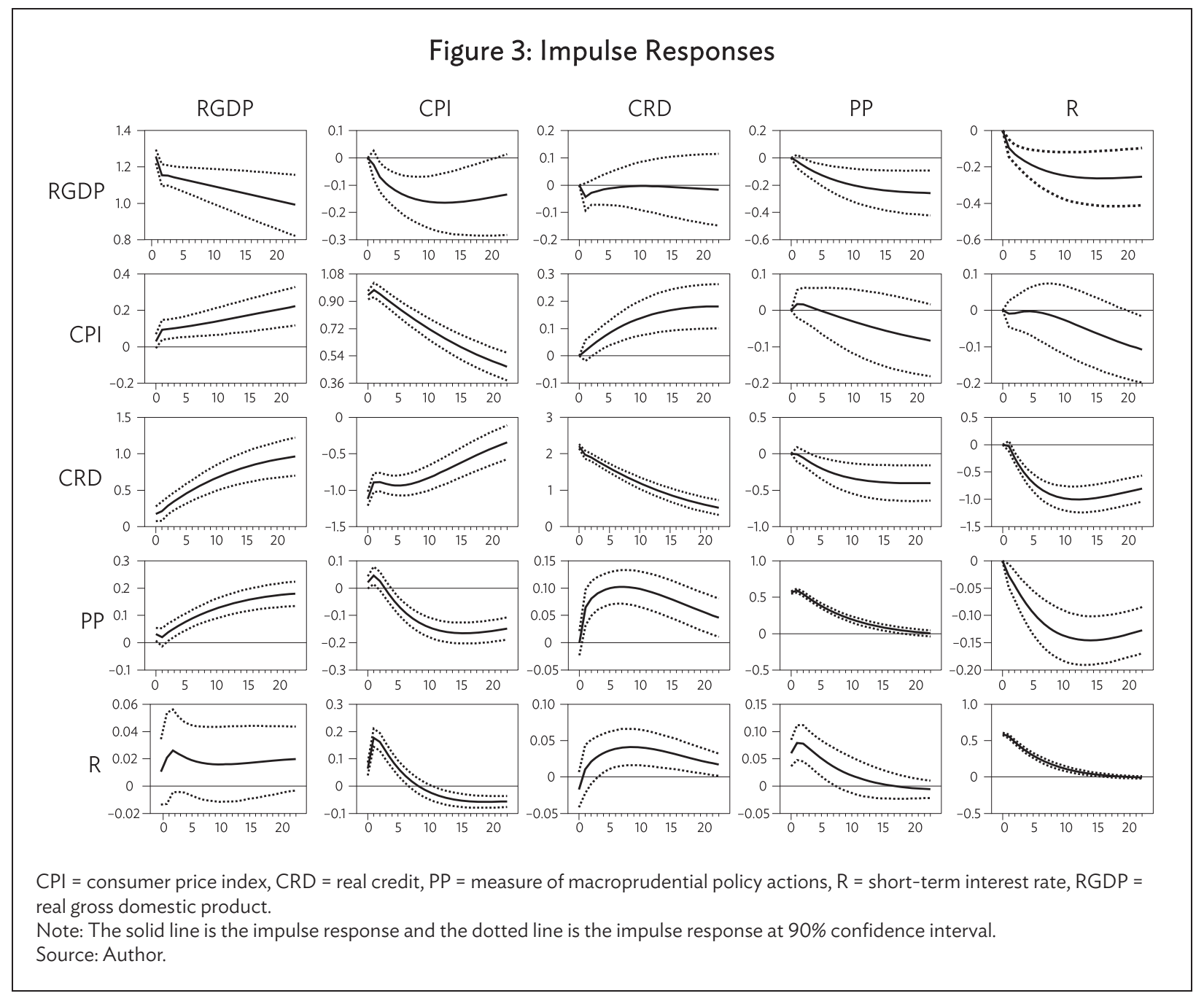

In response to contractionary macroprudential policy shocks, PP increases by about $0.5 \%$, declines over time, and increases to the initial level in about 5 years. The increase in PP is different from 0 with 95\% probability for more than 4 years after the shock. CRD decreases over time and reaches a decline of about $0.4 \%$ in 6 years. The decline in CRD is different from 0 with more than $95 \%$ 
probability after 4 quarters. This suggests that contractionary macroprudential policy shocks decrease CRD significantly, as intended by the policy authorities.

Macroprudential policy shocks also affect aggregate economic activity. Contractionary macroprudential policy shocks decrease RGDP over time, which is different from 0 with more than $95 \%$ probability after 4 quarters. After 6 years, the size of the decline in real GDP is about $0.2 \%$. CPI also tends to decline, although the probability bands include 0 for all horizons. The size of this decline after 6 years is about $0.1 \%$.

These effects of macroprudential policy shocks are similar to monetary policy shocks. In response to contractionary monetary policy, shocks that raise R, RGDP, CPI, and CRD decrease over time. The interest rate increases by $0.6 \%$ on impact, declines over time, and goes back to the initial level in about 4 years. The declines in interest rates are different from 0 with $95 \%$ probability for about 4 years. Credit declines over time: it reaches the maximum decline of $1 \%$ in about 10 quarters and slowly increases over time toward the initial level. The credit decline is different from 0 with $95 \%$ probability from the second quarter after the shock. RGDP declines over time, by $0.2 \%$ in 6 years. The decline in RGDP is different from 0 with $95 \%$ probability from the second quarter after the shock. CPI also declines over time, by $0.1 \%$ in 6 years. The decline in $\mathrm{CPI}$ at the 6 -year horizon is different from 0 with $95 \%$ probability.

There is some debate on the effects of macroprudential policy. Studies including Borio and Drehmann (2009) and Stein (2013) suggest that macroprudential policy often targets specific sectors or practices, but monetary policy has a more widespread impact on the economy. Shin (2015) and others suggest that both policies can lead to a reallocation of spending over time by influencing the availability and cost of credit. They also suggest macroprudential policies may have aggregate demand effects in addition to their impact on financial conditions. Like Kim and Mehrotra (2018a) for four countries in Asia and the Pacific, and Kim and Mehrotra (2018b) for 32 countries, this study supports the latter view.

The interactions between the two policies show interesting patterns. Macroprudential policy shocks increase both PP and R. But monetary policy shocks increase R but decrease PP. In response to PP shocks, $R$ increases by $0.06 \%$ on impact, it further increases to $0.075 \%$ in the next period, declines, and then reaches the initial level in about 4 years. The increase in $\mathrm{R}$ is different from 0 with $95 \%$ probability up to 6 quarters after the shock. In response to R shocks, PP decreases over time, reaches the maximum effect of $-0.15 \%$ in about 3 years, and then tends to slowly increase. The decline in PP is different from 0 from the second quarter after the shock. When policy authorities increase R, CRD decreases, so loosening macroprudential policy can be taken to stabilize CRD. But when macroprudential policy tightens, monetary policy also tightens, which may suggest a complementary action of two policies.

In response to CRD shocks, PP and $\mathrm{R}$ increase significantly. CRD increases by $2.2 \%$ on impact, and then tends to decrease over time. Six years after the shock, CRD is still larger than the initial level, by $0.5 \%$. The increase in CRD is different from 0 with $95 \%$ probability in all horizons. PP increases over time, reaches the maximum effect of $0.1 \%$ in 7 quarters, and then decreases over time. PP is still larger than the initial level by $0.05 \%$ in 6 years. The increase is different from 0 , with $95 \%$ probability from the second quarter after the shock. R drops slightly on impact but increases over time, reaching the maximum effect of $0.04 \%$ in about 9 quarters and then decreases. $R$ is still larger than the initial level by $0.02 \%$ in 6 years. The increase is different from 0 with $95 \%$ probability from the fourth quarter after 
the shock. These results may suggest that in the presence of credit shocks, policy authorities try to reduce excessive credit by tightening both monetary and macroprudential policies.

Table 3 shows the results of forecast error variance decomposition with $90 \%$ probability bands, and the contributions of macroprudential and monetary policy shocks to fluctuations in all the model's variables. Although macroprudential policy has significant effects on RGDP and CRD, the overall contribution of these shocks to fluctuations is quite small-2\% in RGDP, $0.5 \%$ in CPI, and 1.9\% in CRD at the 16-quarter horizon. The contribution of macroprudential policy shocks is smaller than that of monetary policy shocks, which are relatively small but larger than macroprudential policy shocks. The maximum contribution of monetary policy shocks to fluctuations is 3.3\% in RGDP, $0.5 \%$ in CPI, and $15.4 \%$ in CRD at the 16-quarter horizon. Except for the contribution to own variables, the only case in which the contribution is larger than $10 \%$ is for monetary policy shocks on CRD at longer horizons.

The fluctuations in policy instruments PP and R are mostly explained by own shocks. PP shocks explain the huge amount of fluctuations (more than 70\% at any horizon) in PP, and R shocks explain most part of the fluctuations (more than $85 \%$ at any horizon) in R. PP shocks explain a very small part of the fluctuations in $\mathrm{R}$, which is less than $2.5 \%$ at any horizon. $\mathrm{R}$ shocks also explain a small part of the fluctuations in PP, which is less than 7.5\% at any horizon.

\section{Table 3: Forecast Error Variance Decomposition}

(a) Contribution of macroprudential policy shocks

\begin{tabular}{lccccc}
\hline Quarters & RGDP & CPI & CRD & PP & R \\
\hline 4 quarters & $0.2(0.0,1.2)$ & $0.1(0.0,0.7)$ & $0.1(0.0,0.8)$ & $96.4(93.1,98.4)$ & $1.8(0.2,4.8)$ \\
8 quarters & $0.8(0.0,3.2)$ & $0.2(0.0,1.2)$ & $0.6(0.0,2.7)$ & $90.0(83.8,94.6)$ & $2.1(0.3,6.1)$ \\
12 quarters & $1.4(0.1,5.4)$ & $0.3(0.0,2.3)$ & $1.3(0.1,5.1)$ & $80.8(71.3,88.8)$ & $2.2(0.4,6.9)$ \\
16 quarters & $2.0(0.1,7.4)$ & $0.5(0.0,3.3)$ & $1.9(0.1,7.5)$ & $71.7(60.3,82.4)$ & $2.3(0.5,7.4)$ \\
\hline
\end{tabular}

(b) Contribution of monetary policy shocks

\begin{tabular}{lccccc}
\hline Quarters & RGDP & CPI & CRD & PP & R \\
\hline 4 quarters & $0.9(0.1,2.5)$ & $0.1(0.0,0.6)$ & $1.2(0.4,2.9)$ & $0.5(0.0,1.9)$ & $90.3(84.9,94.6)$ \\
8 quarters & $1.9(0.2,5.5)$ & $0.2(0.0,1.5)$ & $6.6(2.7,12.1)$ & $2.5(0.4,6.5)$ & $89.8(83.7,94.4)$ \\
12 quarters & $2.7(0.2,8.4)$ & $0.3(0.0,2.3)$ & $11.7(5.1,20.4)$ & $5.0(1.1,11.7)$ & $89.0(82.8,93.6)$ \\
16 quarters & $3.3(0.2,10.7)$ & $0.5(0.0,3.3)$ & $15.4(6.8,26.4)$ & $7.4(2.0,15.8)$ & $87.8(81.2,92.7)$ \\
\hline
\end{tabular}

$\mathrm{CPI}=$ consumer price index, $\mathrm{CRD}=$ real credit, $\mathrm{PP}=$ measure of macroprudential policy actions, $\mathrm{R}=$ short-term interest rate, $\mathrm{RGDP}=$ real gross domestic product.

Note: Numbers in parentheses are $90 \%$ probability bands.

Source: Author. 


\section{B. Extended Results}

This section analyzes whether there were changes in the effects of macroprudential policies after the global financial crisis. To examine this, two subperiods are considered: precrisis (2000-2006) and postcrisis (2009-2014). Figures 4 and 5 show the impulse responses for these periods.

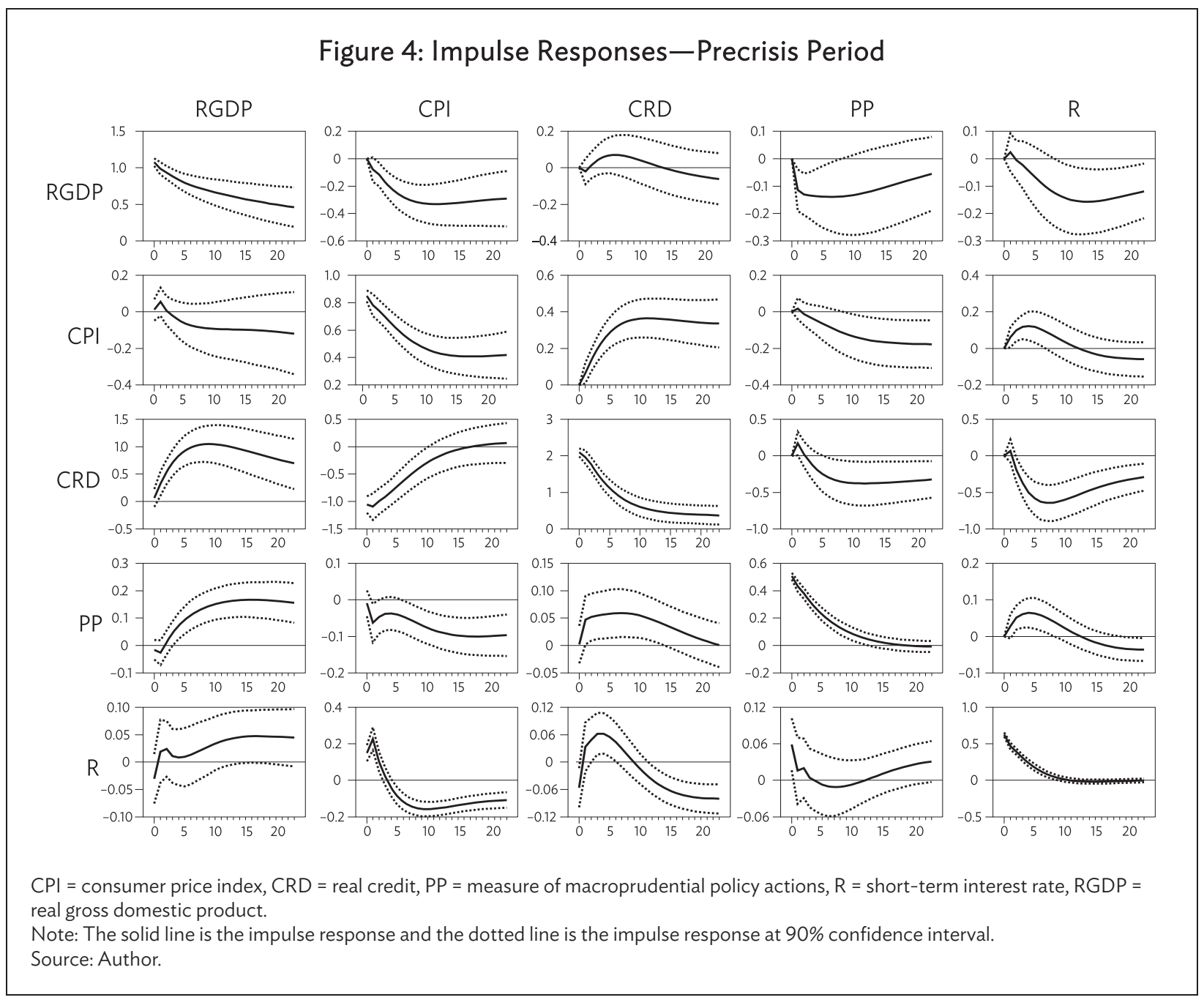


Figure 5: Impulse Responses-Postcrisis Period
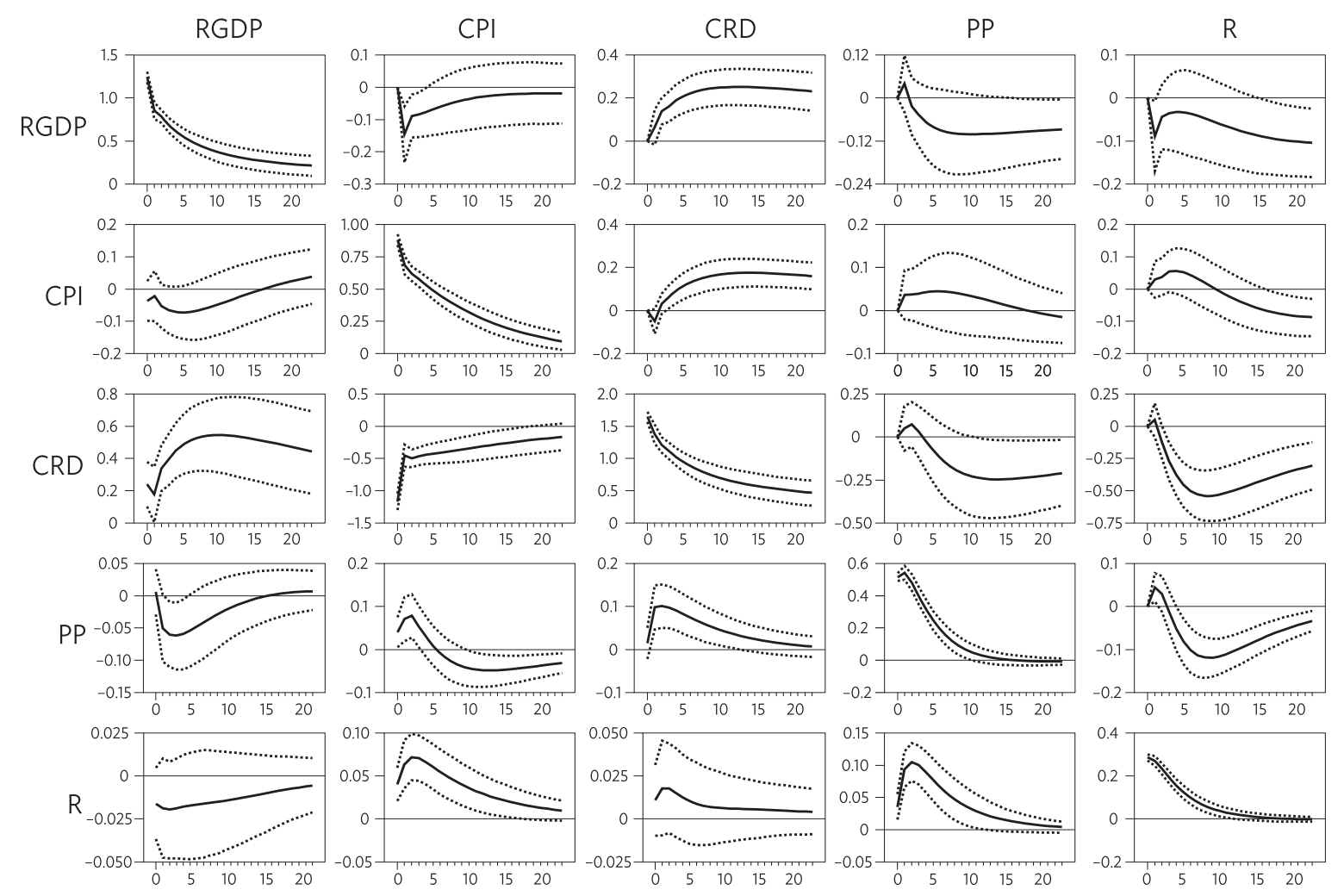

$\mathrm{CPI}=$ consumer price index, $\mathrm{CRD}=$ real credit, $\mathrm{PP}=$ measure of macroprudential policy actions, $\mathrm{R}=$ short-term interest rate, $\mathrm{RGDP}=$ real gross domestic product.

Note: The solid line is the impulse response and the dotted line is the impulse response at $90 \%$ confidence interval.

Source: Author.

The main results are in general similar to those from the baseline model. In particular, the negative effects of macroprudential and monetary policy shocks on RGDP and CRD are different from 0 with $95 \%$ probability in both periods. That is, the effects of PP and R shocks on RGDP and CRD are qualitatively similar in both periods. But there are some notable differences in the impulse responses. First, the effect of macroprudential policy shocks is quantitatively different in the precrisis and postcrisis periods, although it is similar qualitatively. The effect on CRD declines by $0.4 \%$ in the precrisis period but only by $0.25 \%$ in the postcrisis period, although the size of PP responses is similar in both periods, which can be inferred from the impulse responses of PP to PP shocks. The more frequent use of macroprudential policy in the postcrisis period might have led to a weaker effect of macroprudential policy actions postcrisis. However, the PP measure used in this paper only counts the number of changes but not the intensity of each measure-and this might be the result of a weaker measure taken postcrisis or a weaker transmission in that period.

In the precrisis period, macroprudential policy shocks have a quick and huge significant effect on RGDP in the short term, but the effects are not significant in the long term. The maximum effect is found after about 5 quarters with a $0.13 \%$ decline in RGDP. In the postcrisis period, however, macroprudential policy has an insignificant effect on RGDP in the short term, but the long-term effect 
is significant. RGDP declines by $0.08 \%$ in 6 years, which is different from 0 with $95 \%$ probability. The effect on CPI is also different in the two periods. CPI precrisis declines and the negative effect is different from 0 with $95 \%$ probability from 9 quarters after the shock. But the negative effect on CPI is not different from 0 with $95 \%$ probability at any horizon.

Second, the response of macroprudential policy to credit shock is stronger in the postcrisis than the precrisis period. In response to CRD shocks, PP increases up to $0.1 \%$ postcrisis but only up to $0.05 \%$ precrisis. This suggests that macroprudential policy tightens more frequently during CRD shocks in the postcrisis than in the precrisis period. Note that the size of the CRD shocks is even larger in the precrisis than the postcrisis period on the basis of the responses of CRD to CRD shocks. This result is consistent with the notion that macroprudential policy actions were seen as more important and used more in the postcrisis period.

Third, the interactions between the two policies are somewhat different in each period. Postcrisis interactions are similar to those found in the 2000-2014 review period. PP shocks increase PP and R together, but $\mathrm{R}$ shocks increase $\mathrm{R}$ but decrease PP. In the precrisis period, however, PP shocks do not increase $\mathrm{R}$ much, and $\mathrm{R}$ shocks tend to increase PP. The latter result, together with the weak response of PP to CRD shocks, could be interpreted as macroprudential policy having a lesser role in stabilizing credit conditions in the precrisis than in the postcrisis period.

The robustness of the results is checked. First, alternative orderings are considered; in particular, alternative assumptions on the contemporaneous relation of PP with other variables, since the effects of PP shocks are the principle interest of this paper. In these experiments, the main results were found to be unchanged. Figures 6 and 7 show some of these results. The results are reported when all other variables are assumed to be contemporaneously exogenous to PP in Figure 6, and when $\mathrm{PP}$ is assumed to be contemporaneously exogenous to all other variables in Figure 7, which shows the alternative assumption on the ordering between two policy instruments.

Second, dummy variables for the global financial crisis were added, because economies may behave differently during financial crises. A dummy variable is included for each of the 11 economies for the third and the fourth quarters of 2008. Figure 8 shows the results.

The main results in Figures 6, 7, and 8 do not change. The macroprudential policy shocks have significant negative effects on RGDP and CRD, as do monetary policy shocks. Interactions between the two policies are also similar to those in the baseline model: monetary policy shocks decrease PP, but macroprudential policy shocks increase $\mathrm{R}$. 
Figure 6: Impulse Responses-Alternative Ordering 1
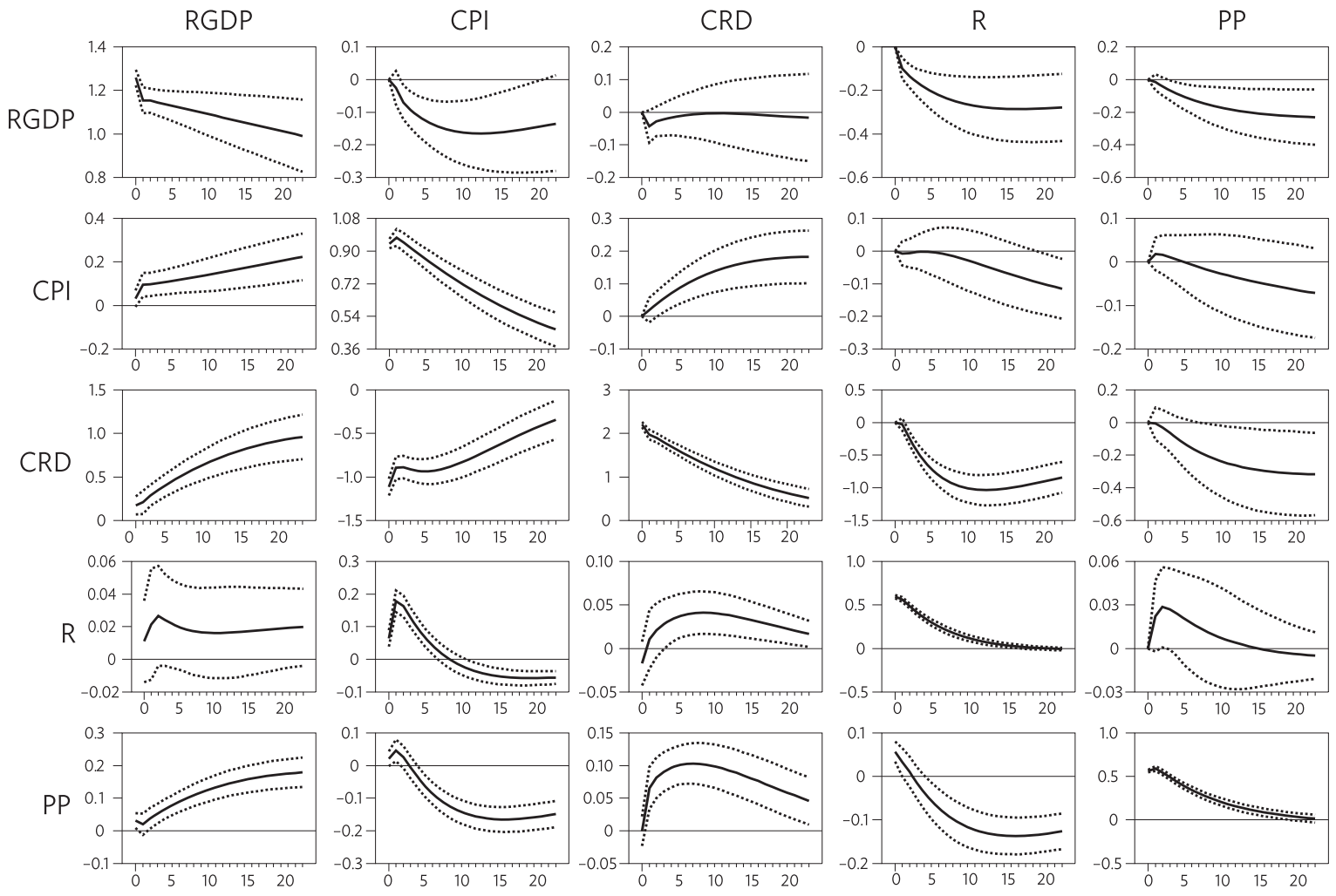

$\mathrm{CPI}=$ consumer price index, $\mathrm{CRD}=$ real credit, $\mathrm{PP}=$ measure of macroprudential policy actions, $\mathrm{R}=$ short-term interest rate, $\mathrm{RGDP}=$ real gross domestic product.

Note: The solid line is the impulse response and the dotted line is the impulse response at $90 \%$ confidence interval. Source: Author. 
Figure 7: Impulse Responses-Alternative Ordering 2

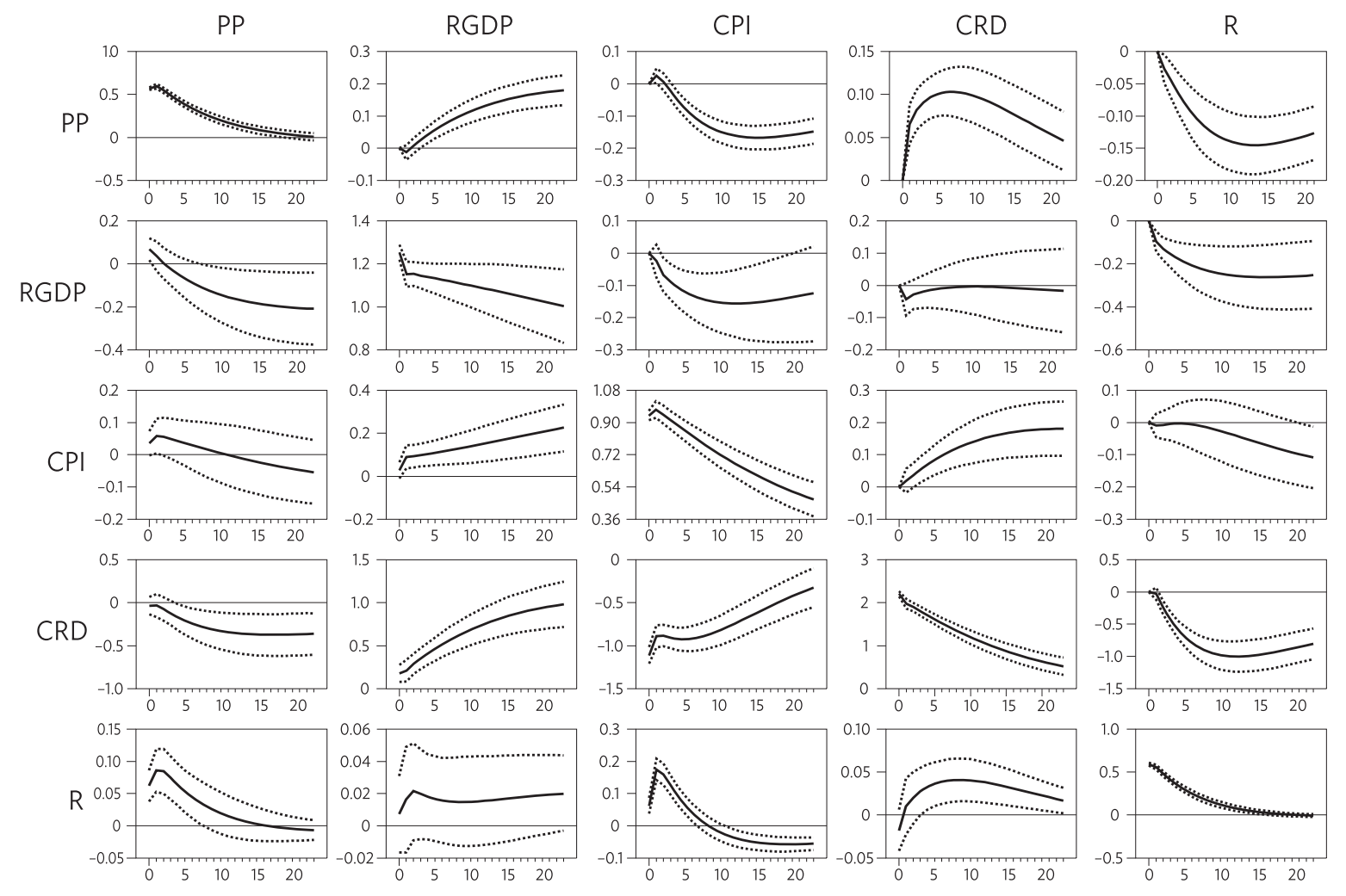

$\mathrm{CPI}=$ consumer price index, $\mathrm{CRD}=$ real credit, $\mathrm{PP}=$ measure of macroprudential policy actions, $\mathrm{R}=$ short-term interest rate, $\mathrm{RGDP}=$ real gross domestic product.

Note: The solid line is the impulse response and the dotted line is the impulse response at $90 \%$ confidence interval.

Source: Author. 


\section{Figure 8: Impulse Responses-Adding Global Financial Crisis Dummies}
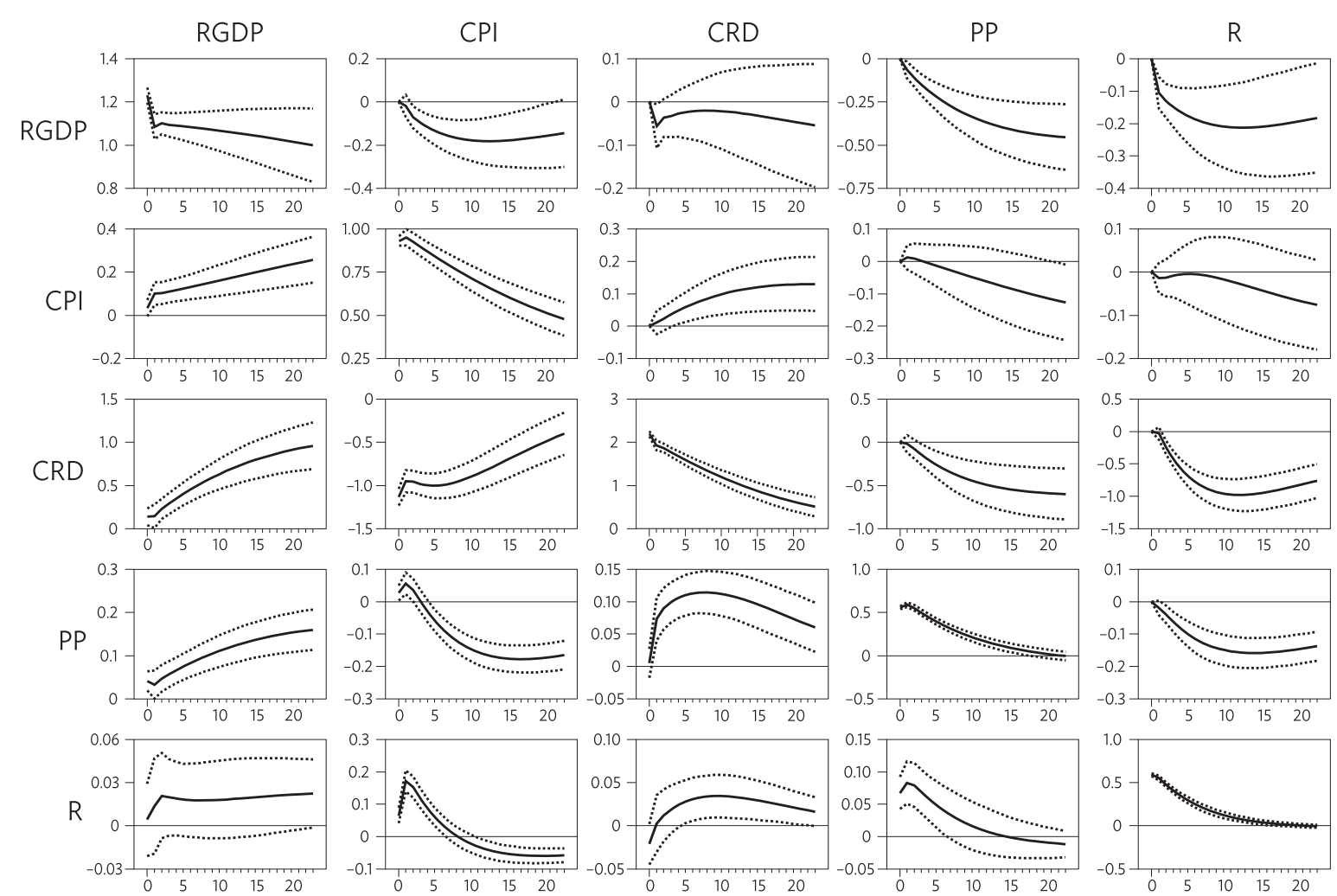

$\mathrm{CPI}=$ consumer price index, $\mathrm{CRD}=$ real credit, $\mathrm{PP}=$ measure of macroprudential policy actions, $\mathrm{R}=$ short-term interest rate, $\mathrm{RGDP}=$ real gross domestic product.

Note: The solid line is the impulse response and the dotted line is the impulse response at $90 \%$ confidence interval.

Source: Author.

\section{Credit and Business Cycles}

The empirical results show that both monetary and macroprudential tightening have significant negative effects on credit and output. When credit and business cycles are synchronized, policy authorities can use either macroprudential or monetary policy to stabilize credit and business cycle conditions. For example, when credit expands excessively and the economy is overstimulated, either contractionary monetary or contractionary macroprudential policy can be used to stabilize credit conditions and cool the economy. Both monetary and macroprudential tightening can also be used simultaneously to increase the stabilizing effects.

When credit and business cycles are not synchronized, the policy authorities may face a dilemma. For example, conflicts may arise when credit expands excessively but the economy is in recession. Tightening macroprudential policy to stabilize credit conditions adds to the problem of economies already in recession. But expanding monetary policy to stimulate the economy will increase already excessive credit. 
The following discussion examines whether such a period of potential policy conflict-in other words, excessive credit conditions and recession-existed in the review period. For each of the 11 economies, a business cycle indicator is constructed by subtracting real GDP from Hodrick-Prescott filtered real GDP, and a credit cycle indicator constructed by subtracting real credit from HodrickPrescott filtered real credit. ${ }^{3}$

Figure 9 shows the results. In the PRC, cyclical credit is above 0 from 2002, but the economy goes into recession from late 2002. The policy authorities may have faced a policy conflict in that year. In the Republic of Korea, cyclical credit started to increase from 2005 and peaked during the global financial crisis, when the country went into recession. This may suggest that the Republic of Korea also faced this dilemma during the crisis. Similar situations are also found in other economies in the sample: the early 2000s in Indonesia, Malaysia, and the Philippines; and India during the global financial crisis, for example.

Historical data show that Asian countries already experienced periods of potential policy conflicts in the review period. This indicates that they will experience a recurrence of such periods in the future. Asian countries therefore need to prepare for future policy conflicts by clearly understanding the effects of macroprudential policy.

There may be some ways of mitigating the problem by understanding the effects of macroprudential policy more clearly. First, macroprudential and monetary policy may have different relative effects on output and credit. In this case, a combination of both policies may solve the problem. For example, if macroprudential policy has a stronger effect on CRD but monetary policy has a stronger effect on output, then the simultaneous use of macroprudential policy tightening and monetary policy expansion may decrease CRD and increase output. ${ }^{4}$

Second, each instrument of macroprudential policy may have a different effect. For example, some macroprudential policy instruments may have a smaller effect on the aggregate economy than others, while all have a similar effect on credit. In this case, tightening a macroprudential policy instrument and expanding monetary policy may stabilize credit conditions and stimulate output. Kim and Mehrotra (2018b) analyze the effects of each macroprudential policy instrument.

If it is hard to see any difference between the effects of monetary and macroprudential policies, other macro policies can be used in conjunction with them. For example, if fiscal policy has only a weak effect on credit but a strong one on output, fiscal expansion can be used with tightening actions in macroprudential or monetary policy.

\footnotetext{
3 As usual in business cycle studies, the lambda is set to 1,600 to calculate the business cycle indicator. As before, the lambda is set to 400,000 to calculate the credit cycle indicator.

4 This is discussed in Kim and Mehrotra (2017, 2018a) and Kim (2016).
} 


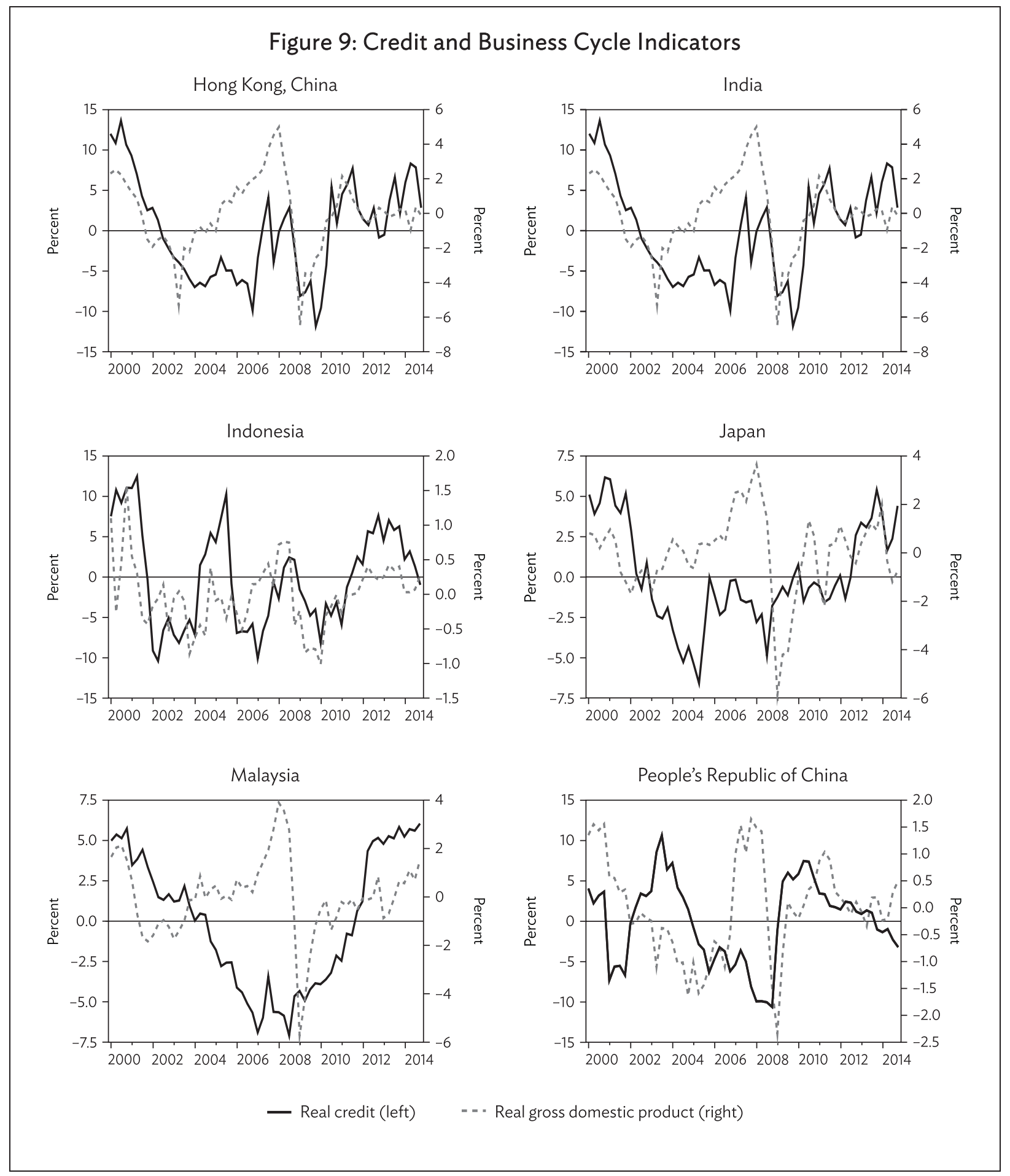




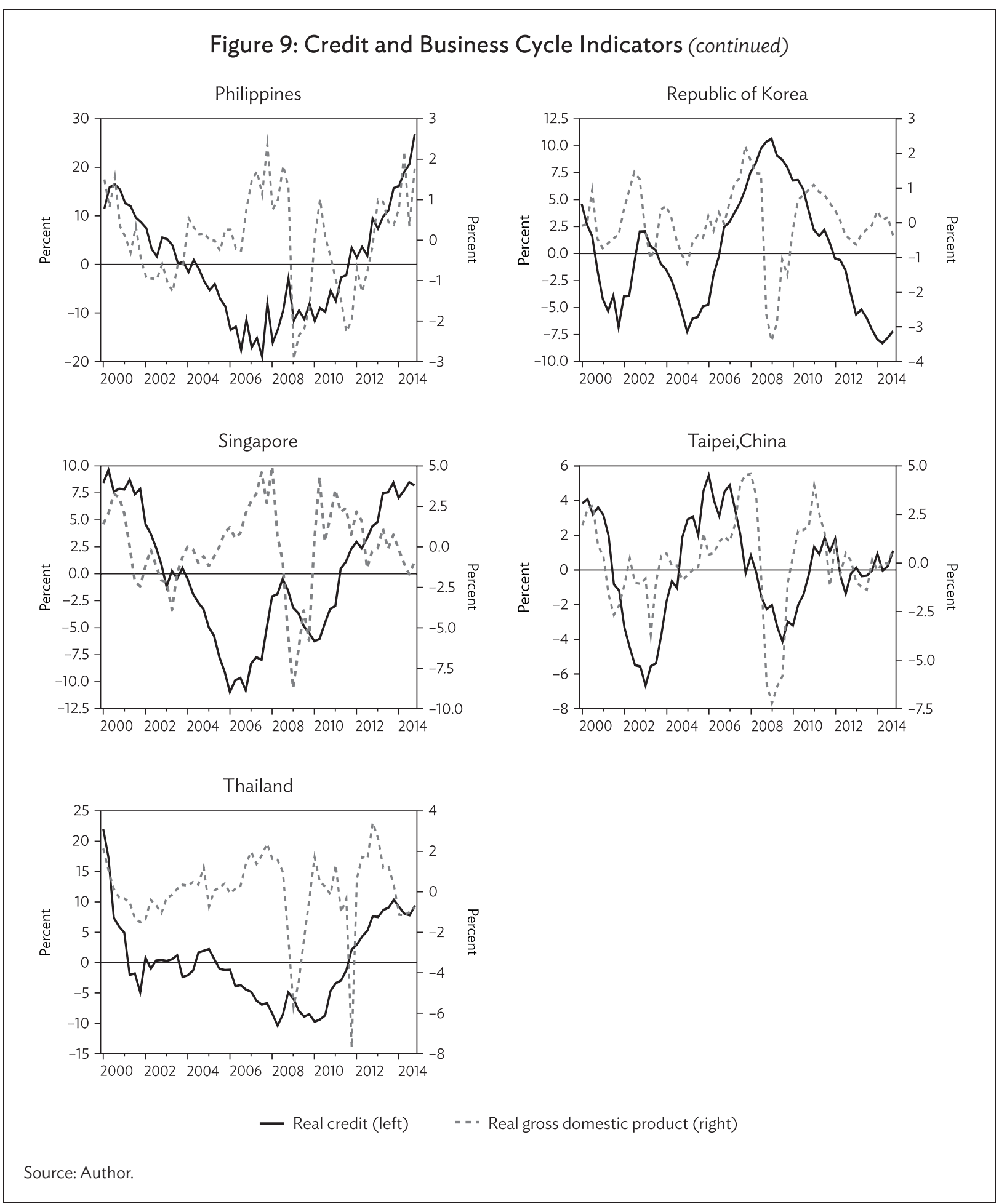




\section{CONCLUSIONS}

This paper analyzed the conduct and the effects of macroprudential policy in 11 Asian economies. It first documents some stylized facts on the conduct of macroprudential policy in Asia. Some of these economies, including India, the PRC, and the Republic of Korea, frequently used macroprudential policy tools, including loan-to-value ratios and required reserve ratios, even before the global financial crisis. Since 2000, the PRC and India have been the most frequent users of macroprudential policy tools. Macroprudential policy was tightened more frequently than it was loosened in the 11 economies, especially after the global financial crisis. In most of them, macroprudential policy tends to be tightened when credit expands.

The empirical results from the analysis of the effects of macroprudential policy shocks using panel VAR models show that macroprudential policy tightening has a significant negative effect on credit conditions, which can be regarded as a target of macroprudential policy. This tightening also has a significant negative effect on output. These effects of macroprudential policy are qualitatively similar to the effects of monetary policy. But the overall contribution of macroprudential policy shocks on fluctuations in credit, output, and the price level is small.

The similar effects of monetary and macroprudential policies on credit and output may suggest that Asian countries can encounter policy conflicts when credit expands excessively and the economy is in recession. Indeed, many Asian countries have already experienced this condition since 2000. These countries need to prepare for a recurrence of these conflicts in the future by having a clear understanding of the effects of macroprudential policy and traditional macro policy on credit conditions. 


\section{REFERENCES}

Borio, Claudio E., and Mathias Drehmann. 2009. "Assessing the Risk of Banking Crises- Revisited." BIS Quarterly Review, March, 29-46.

Cerutti, Eugenio, Stijin Claessens, and Luc Laeven. 2017. "The Use and Effectiveness of Macroprudential Policies: New Evidence.” Journal of Financial Stability 28 (C): 203-24.

Christiano, Lawrence, Martin Eichenbaum, and Charles Evans. 1999. "Monetary Policy Shocks: What Have We Learned and To What End?" In Handbook of Macroeconomics, Vol. 1A, edited by John B. Taylor and Michael Woodford. Amsterdam: North Holland.

IMF-BIS Financial Stability Board. 2011. Macroprudential Policy Tools and Frameworks-Progress Report to G20. https://www.bis.org/publ/othp17.htm.

Kaminsky, Graciela L., and Carmen M. Reinhart. 1999. "The Twin Crises: The Causes of Banking and Balance-of-Payments Problems.” American Economic Review 89 (3): 473-500.

Kim, Soyoung, and Aaron Mehrotra. 2017. "Managing Price and Financial Stability Objectives in Inflation Targeting Economies in Asia and the Pacific." Journal of Financial Stability 29: 106-16.

- 2018a. "Effects of Macroprudential and Monetary Policies: Evidence from Four Inflation Targeting Economies." Journal of Money, Credit, and Banking 50 (5): 967-92.

- 2018b. "Examining Macroprudential Policy and Its Macroeconomic Effects: Some New Evidence." Unpublished. Seoul National University.

Schularick, Moritz, and Alan M. Taylor. 2012. "Credit Booms Gone Bust: Monetary Policy, Leverage Cycles, and Financial Crises, 1870-2008." American Economic Review 102 (2): 1029-61.

Shin, Hyun Song. 2015. "Macroprudential Tools, Their Limits and Their Connection with Monetary Policy." Panel Speech at the International Monetary Fund's Spring Meeting: Rethinking Macro Policy III: Progress of Confusion? Washington, DC: International Monetary Fund.

Sims, Christopher A. 1980. "Macroeconomics and Reality." Econometrica 48 (1): 1-48.

Stein, Jeremy C. 2013. "Overheating in Credit Markets: Origins, Measurement, and Policy Responses." Speech at the Restoring Household Financial Stability after the Great Recession: Why Household Balance Sheets Matter. Symposium. St. Louis.

Wu, Jing Cynthia, and Fan Dora Xia. 2016. "Measuring the Macroeconomic Impact of Monetary Policy at the 0 Lower Bound." Journal of Money, Credit, and Banking 48 (2-3): 253-91. 


\section{Macroprudential Policy in Asian Economies}

This paper analyzes macroprudential policy in 11 Asian economies since 2000 and examines its effect on financial stability and key macroeconomic variables. The findings suggest that policy authorities may experience policy conflicts in achieving financial and macroeconomic stability objectives. Since the global financial crisis, special attention has been paid to macroprudential policy to attain macroeconomic stability by securing financial stability.

\section{About the Asian Development Bank}

ADB is committed to achieving a prosperous, inclusive, resilient, and sustainable Asia and the Pacific, while sustaining its efforts to eradicate extreme poverty. Established in 1966, it is owned by 68 members -49 from the region. Its main instruments for helping its developing member countries are policy dialogue, loans, equity investments, guarantees, grants, and technical assistance.

$\mathrm{ADB}$ 